\title{
PENGALIHAN BENTUK PERUSAHAAN UMUM (PERUM) KERETA API MENJADI PERUSAHAAN PERSEROAN PT KERETA API INDONESIA (Persero)
}

\author{
Dhevi Nayasari Sastrdinata, S.H.,M.M. \\ dhevinss@unisla.com
}

Fakultas Hukum Universitas Islam Lamongan

\begin{abstract}
ABSTRAK
Pengalihan status Perumka menjadi PT. Kereta api (Persero) diatur dalam Peraturan Pemerintah No.19 tahun 1998, adanya pengalihan bentuk perusahaan tersebut menyebabkan perubahan terhadap hak-hak karyawan PT Kereta Api Indonesia (Persero). Permasalahan yang dibahas pada Penelitian ini bertujuan untuk mengetahui pengaturan tentang proses pengalihan bentuk perusahaan Kereta Api menjadi Perseroan Terbatas serta untuk mengetahui hak-hak karyawan setelah adanya pengalihan bentuk perusahaan Kereta Api menjadi Perseroan Terbatas. Tipe penelitian hukum yang dilakukan adalah yuridis normatif dengan mengunakan pendekatan perundang-undangan. Bahan hukum yang dipergunakan dalam penelitian ini berupa bahan hukum primer, sekunder, dan tersier.Perseroan terbatas (PT) diatur dalam Undang-Undang No. 40 tahun 2007 sedangkan BUMN diatur dalam UndangUndang No. 19 Tahun 2003. Dalam undang-undang BUMN disebutkan hanya ada dua BUMN di Indonesia yaitu perum dan persero, yang didalamnya termasuk PT Kereta Api Indonesia (Persero). perkeretaapian di Indonesia sendiri beberapa kali berganti badan hukum dimana tujuannya adalah menciptakan tata kelola perusahaan yang baik(good corporate governance), sehingga dapat memenuhi hak-hak pegawai. pada masa perumka hak-hak pegawai kereta api terabaikan disebabkan tidak dikeluarkannya surat keputusan bersama tiga menteri sesuai Pasal 57 Peraturan Pemerintah No. 57 Tahun 1990 serta belum adanya perjanjian kerja bersama antara serikat pekerja dengan perusahaan, sedangkan pada masa PT Kereta Api Indonesia (persero) hak-haknya sudah jelas tercantum dalam pasal-pasal PKB tahun 2017-2019.
\end{abstract}

\section{Kata kunci: pengalihan, perum, PT KAI (persero)}

\section{A. PENDAHULUAN}

\section{- Latar Belakang Masalah}

PT Kereta Api Indonesia (Persero) merupakan salah satu Badan Usaha Milik Negara (BUMN) yang dimiliki Indonesia yang dikhususkan untuk menyelenggarakan jasa angkutan kereta api terutama angkutan penumpang dan barang. ${ }^{1}$

Perkeretaapian di Indonesia mulai ada pada masa penjajahan Belanda, dengan didirikannya perusahan swasta Nederland Indishche Spoorwegmij (NISM) dan ditandai dengan pembangun jalur kereta pertama kemijen-tanggung pada tanggal 17 juni 1864. Pada tanggal 10 april 1869 Belanda mendirikan perusahaan milik pemerintah dengan nama Staats Spoorwegen (SS), perkembangan pembanguan jalur kereta api berkembang

\footnotetext{
${ }^{1}$ Hadi M Djuraid. jonan dan evolusi kereta api
} indonesia. Jakarta. 2013. h.43 sangat pesat pada masa penjajahan Belanda dengan ditandainya pembangunanpembangunan jalur baru yang dilakukan belanda. $^{2}$

Pada tahun 1942 Belanda menyerah kepada Jepang, perkeretaapian di Jawa pada saat itu dikuasai oleh pemerintah angkatan darat (Rikuyun). Sedangkan di Sumatra dikuasai oleh angkatan laut Jepang (Kaigun) dengan nama Tetsudo Tai pusatnya di Bukit Tinggi. ${ }^{3}$

Pada tanggal 28 september 1945 awal dari sejarah perkeretaapian di Indonesia dengan ditandainnya pengambil alihan yang dilakukan oleh Angkatan Moeda Kereta Api (AMKA) terhadap jepang. Dengan pengambil alihan perkeretaapian dari jepang oleh AMKA itu lah menjadi sejarah awal berdirinya

\footnotetext{
${ }^{2}$ Yati nurhayati. Sejarah kereta api Indonesia. Bandung. 2014. h.54

${ }^{3}$ ibid. h. 57
} 
Djawatan Kereta Api Republik Indonesia (DKARI). ${ }^{4}$

Pada tanggal 1 januari 1950 didirikan Djawatan Kereta api (DKA) dengan dasar UUD 1945 pasal 33 bahwa kereta api harus dikuasai negara karena dikategorikan sebagai cabang produksi penting bagi Negara yang menguasai hajat hidup orang banyak, DKA merupakan gabungan DKRI dan SS/VS. pada tanggal 25 mei 1963 berdasarkan Peraturan Pemerintah No.22 tahun 1963 Djawatan Kereta Api dirubah menjadi Perusahaan Negara Kereta Api (PNKA). ${ }^{5}$

Pada tahun 1971 berdasarkan Peraturan Pemerintah No.61 tahun 1971 kereta api dirubah dari Perusahaan Negara Kereta Api (PNKA) menjadi Perusahaan Jawatan Kereta Api (PJKA). Pada tahun 1990 berdasarkan PP No.57 tahun 1990 perkeretaapian diindonesia kembali melakukan perubahan bentuk menjadi Perusahaan Umum Kereta Api (PERUMKA). Dan pada tahun 1998 berdasarkan PP No.19 tahun 1998 berubah menjadi PT Kereta Api (Persero). ${ }^{6}$

Hingga saat ini bentuk perusahaan perseroan terbatas masih dipergunakan. Hanya saja pada tahun 2010 ada perubahan nama perusahaan dengan menambahkan kata Indonesia pada nama perseroan karena direksi menganggap penting untuk menambahkan kata Indonesia pada nama perseroan. Dengan dikeluarkannya Instruksi Direksi No. 16/OT.203/KA 2010, sehingga nama resmi perseroan berubah menjadi PT Kereta Api Indonesia (Persero). ${ }^{7}$

Perubahan bentuk badan hukum perusahaan merupakan sebagai upaya perubahan pengelolaan perusahaan sesuai prinsip Good Corporate Governance (GCG). Dalam Undang-Undang No. 19 tahun 2003 tentang Badan Usaha Milik Negara (BUMN) hanya ada dua jenis perusahan milik negara, yaitu PERSERO dan Perusahaan Umum (PERUM). Dalam undang-undang No. 19 tahun 2003 Kedua jenis perusahaan milik negara tersebut mempunyai maksud dan tujuan yang berbeda.

Perubahan terhadap segala hal yang berhubungan dengan perkeretaapian di indonesia, salah satunya berhubungan dengan hak-hak karyawannya disebakan karena adanya pengalihan bentuk perusahaan kereta api menjadi perseroan

\footnotetext{
${ }^{4}$ Ibid. h.59

${ }^{5}$ Ibid. h.59-60

${ }^{6}$ Ibid. h.59-h.61

${ }^{7}$ Hadi M Djuraid. jonan dan evolusi kereta api indonesia. Jakarta. 2013. h.218
}

terbatas. Dengan adanya pengalihan bentuk perusahan Kereta Api tersebut aturan mengenai kepegawaian Badan Usaha Milik Negara (BUMN) pada awalnya dipersamakan dengan Pegawai Negeri Sipil (PNS) karena belum ada aturan khusus yang mengatur tentang kepegawaian BUMN. Akan tetapi sejak diterbitkannya Peraturan Pemerintah No. 45 Tahun 2005 tentang Pendirian, Pengurusan, Pengawasan, dan Pembubaran Badan Usaha Milik Negara, segala ketentuan kepegawaian pada Pegawai Negeri Sipil tidak berlaku lagi terhadap Pegawai/Karyawan Badan Usaha Milik Negara sebagaimana dijelaskan dalam Pasal 95 Peraturan Pemerintah No. 45 tahun 2005.

Dapat disimpulakn bahwa tidak ada aturan khusus yang mengatur tentang hak-hak karyawan BUMN, oleh sebab itu aturan yang mengatur tentang hak-hak karyawan BUMN diterangkan dalam Undang-Undang Ketenagakerjaan, Peraturan Perusahaan dari Badan Usaha Milik Negara yang berlaku pada setiap perusahaan, dan Perjanjian Kontrak Bersama (PKB) antara serikat pekerja dengan perusahaan yang sudah disepakati bersama.

Adapun rumusan masalah dengan sistem normatif yang akan dibahas didalam penelitian ini adalah:

1. Bagaimana pengaturan tentang proses pengalihan bentuk Perusahaan Kereta Api menjadi Perseroan Terbatas? 2.

\section{B. METODE PENELITIAN}

\section{Tipe Penelitian}

Tipe penelitian hukum yang dilakukan adalah yuridis normatif (hukum normatif). Metode penelitian hukum normatif adalah suatu prosedur penelitian ilmiah untuk menemukan kebenaran berdasarkan logika keilmuan hukum dari sisi normatifnya. 8

Oleh karena itu penelitian hukum ini difokuskan untuk mengkaji penelitian hukum tentang kaidahkaidah atau norma-norma dalam hukum positif, yakni norma hukum yang terkait dengan hak-hak karyawan PT Kereta Api Indonesia setelah pengalihan bentuk Perusahaan Kereta Api menjadi Perseroan Terbatas.

${ }^{8}$ Johnny Ibrahim, Teori \& Metode Penelitian Hukum Normatif, Banyumedia Publishing, Malang 2006, h..57 


\section{HASIL PENELITIAN dan}

\section{PEMBAHASAN}

\section{- PENGaturan TENTANG PROSES PENGALIHAN BENTUK PERUSAHAAN KERETA API MENJADI TERBATAS PERSEROAN}

\begin{abstract}
Setiap penelitian pastilah mempunyai tujuan, tujuan penulis melakukan penelitian ini agar masyarakat bisa mengetahui pengaturan tentang proses pengalihan bentuk Perusahaan Kereta Api menjadi Perseroan Terbatas danuntuk mengetahui hak-hak karyawan setelah adanya pengalihan bentuk Perusahaan Kereta Api menjadi Perseroan Terbatas.
\end{abstract}

\section{A. Perseroan Terbatas (PT)}

Perseroan terbatas atau dalam bahasa inggris company limited by shares, dan dalam bahasa belanda naamloze vennootschap, sedangkan menurut pasal 1 ayat 1 UndangUndang Nomor 1 tahun 1995 tentang perseroan terbatas sebagai berikut ${ }^{9}$ :

\begin{abstract}
"Perseroan Terbatas adalah badan hukum yang didirikan berdasarkan perjanjian, melakukan kegiatan usaha dengan modal dasar yang seluruhnya terbagi dalam saham dan memenuhi persyaratan yang ditetapkan undang-undang ini serta peraturan pelaksanaannya".
\end{abstract}

Adapun menurut pasal 1 ayat 1 Undang-Undang Nomor 40 tahun 2007 tentang Perseroan Terbatas sebagai berikut :

"Perseroan Terbatas adalah badan hukum yang merupakan persekutuan modal, didirikan berdasarkan perjanjian, melakukan kegiatan usaha dengan modal dasar yang seluruhnya terbagi dalam saham dan memenuhi persyaratan yang ditetapkan dalam undang-undang ini serta peraturan pelaksanaannya".

Dasar hukum tentang Perseroan terbatas (PT) diatur dalam UndangUndang No. 40 tahun 2007 tentang Perseroan Terbatas, UndangUndang ini sebagai penganti Undang-Undang sebelumnya yaitu Undang-Undang No. 1 Tahun 1995. Undang-Undang No. 40 tahun 2007 berlaku pada tanggal 16 Agustus tahun 2007 yang diundangkan melalui Lembaran Negara No. 106 Tahun 2007, secara otomatis Undang-Undang No.1 Tahun 1995 tidak berlaku lagi karena sudah digantikan dengan Undang-Undang yang baru.

Perseroan terbatas didirikan mempunyai maksud dan tujuan, maksud dan tujuan yang dimaksud adalah maksud dan tujuan pendirian dari Perseroan Terbatas tersebut bukan maksud dan tujuan dari masing-masing orang yang mendirikan Perseroan terbatas tersebut. Upaya yang dilakukan untuk mencapai maksud dan tujuan itu perseroan terbatas melakukan kegiatan usaha. ${ }^{10}$ Menurut pasal 2 undang-undang perseroan terbatas maksud dan tujuan sebagai berikut :

"Perseroan harus mempunyai
maksud dan tujuan serta
kegiatan usaha yang tidak
bertentangan
ketentuan dengan
perundang-undangan,
ketertiban umum, dan/atau
kesusilaan".
ksud dan tujuan serta kegiatan
aha tersebut dicantumkan
alam anggaran dasar sesuai
gan isi pasal 18 Undang-
dang No. 40 tahun 2007 sebagai
kut:

"Perseroan harus mempunyai maksud dan tujuan serta kegiatan usaha yang dicantumkan dalam anggaran dasar Perseroan sesuai dengan ketentuan peraturan perundangundangan”.

\footnotetext{
${ }^{9}$ Abdul R. Saliman. Hukum Bisnis Untuk Perusahaan. Kencana. Jakarta 2005. Cetakan Keenam. h.95
}

\footnotetext{
10 Janus Sidabalok. Hukum Perusahaan. Nuansa Aulia. Bandung 2012. h.120
} 


\section{B. Badan Usaha Milik Negara (BUMN)}

Undang-Undang No. 19 Tahun 2003 Tentang Badan Usaha Milik Negara (Undang-Undang BUMN) sebagai landasan hukum untuk melakukan kegiatan perusahaan BUMN yang ada di Indonesia. Undang-Undang No. 19 Tahun 2003 merupakan sebagai UndangUndang pengganti Undang-Undang sebelumnya. Undang-Undang No. 19 Tahun 2003 diundangkan mulai tanggal 19 juni 2003 dan sekaligus menjadi tanggal pemberlakuan Undang-Unadang tersebut. ${ }^{11}$

Perusahaan negara dipahami sebagai perusahaan yang didirikan oleh negara dan modalnya milik negara. Dapat juga disebut dengan Badan Usaha Milik Negara (BUMN). ${ }^{12}$

Definisi Badan Usaha Milik Negara menurut pasal 1 angka 1 dan angka 9 Undang-Undang No. 19 Tahun 2003:

\begin{abstract}
"Badan Usaha Milik Negara, yang selanjutnya disebut BUMN, adalah badan usaha yang seluruh atau sebagian besar modalnya dimiliki oleh negara melalui penyertaan secara langsung yang berasal dari kekayaan negara yang dipisahkan, sedangkan Direksi adalah organ BUMN yang bertanggung jawab atas pengurusan BUMN untuk kepentingan dan tujuan BUMN, serta mewakili BUMN baik di dalam maupun di luar pengadilan".
\end{abstract}

Bentuk Badan Usaha Milik Negara yang ada di Indonesia saat ini hanya ada dua yaitu terdiri dari Perseroan (PERSERO) dan Perusahaan Umum (PERUM) sesuai dengan Pasal 9 UndangUndang No 19 Tahun 2003 tentang Badan Usaha Milik Negara. ${ }^{13}$

\section{Perusahaan Umum (Perum)}

Pengertian Perusahaan Umum (PERUM) diterangkan dalam pasal
1 angka 4 Undang-Undang No. 19 Tahun 2003 tentang tentang Badan Usaha Milik Negara sebagai berikut:

"Perusahaan Umum, yang selanjutnya disebut Perum, adalah BUMN yang seluruh modalnya dimiliki negara dan tidak terbagi atas saham, yang bertujuan untuk kemanfaatan umum berupa penyediaan barang dan/atau jasa yang bermutu tinggi dan sekaligus mengejar keuntungan berdasarkan prinsip pengelolaan perusahaan".

Pemerintah mendirikan Perusahaan Umum (PERUM) dilakukan secara sepihak dengan perundang-undangan dan sejak pendiriannya otomatis memperoleh status sebagai badan hukum. ${ }^{14}$ Pendirian Perum diusulkan oleh Menteri kepada Presiden disertai dengan dasar pertimbangan setelah dikaji bersama dengan Menteri Teknis dan Menteri Keuangan, memperoleh status badan hukum sejak diundangkannya Peraturan Pemerintah tentang pendiriannya, Ketentuan lebih lanjut mengenai pendirian, pembinaan, pengurusan, dan pengawasan Perum diatur dengan Peraturan Pemerintah. (pasal 35 Undang-Undang No. 19 Tahun 2003) ${ }^{15}$

Maksud dan tujuan perum menurut pasal 36 Undang-Undang No. 19 Tahun 2003 tentang Badan Usaha Milik Negara menyatakan:

“(1) Maksud dan tujuan Perum adalah menyelenggarakan usaha yang bertujuan untuk kemanfaatan umum berupa penyediaan barang dan/atau jasa yang berkualitas dengan harga yang terjangkau oleh masyarakat berdasarkan prinsip pengelolaan perusahaan yang sehat".

“(2) Untuk mendukung kegiatan dalam rangka mencapai

\footnotetext{
${ }^{11}$ Abdulkadir Muhammad. Op.cit. h.169

12 Janus Sidabalok. Op.cit. h.66

${ }^{13}$ Abdulkadir Muhammad. Op.cit. h.170
}

\footnotetext{
${ }^{14}$ Janus Sidabalok. Op cit. h.75

${ }^{15}$ Abdulkadir Muhammad. Op cit. h.189
} 


maksud dan tujuan
sebagaimana dimaksud
dalam ayat (1), dengan
persetujuan Menteri, Perum
dapat melakukan
penyertaan modal dalam
badan usaha lain".

\section{Perseroan (Persero)}

Pengertian Perseroan (PERSERO) diterangkan dalam pasal 1 angka 2 Undang-Undang No. 19 Tahun 2003 tentang Badan Usaha Milik Negara sebagai berikut:

"Perusahaan Perseroan, yang selanjutnya disebut Persero, adalah BUMN yang berbentuk perseroan terbatas yang modalnya terbagi dalam saham yang seluruh atau paling sedikit $51 \%$ (lima puluh satu persen) sahamnya dimiliki oleh Negara Republik Indonesia yang tujuan utamanya

keuntungan".

Badan Usaha Milik Negara PERSERO didirikan oleh pemerintah dengan menggunakan peraturan perundang-undangan, berbeda dengan badan usaha swasta yang didirikan dengan adanya perjanjian. Perusahaan Perseroan (PERSERO) berstatus badan hukum sejak pendiriannya. Berbeda dengan Perseroan Terbatas milik swasta yang memperoleh status badan hukum setelah mendapat pengesahan dari pemerintah, Persero tidak memerlukan pengesahaan. ${ }^{16}$

Pendirian PERSERO diusulkan oleh Menteri kepada Presiden disertai dengan dasar pertimbangan setelah dikaji bersama dengan Menteri Teknis dan Menteri Keuangan, pelaksanaan pendirian Persero dilakukan oleh Menteri dengan memperhatikan ketentuan peraturan perundangan-undangan sesuai dengan ketentuan pasal 10 Undang-Undang No. 19 Tahun 2003 tentang Badan Usaha Milik Negara. ${ }^{17}$

Tujuan pendirian PERSERO adalah menyediakan barang dan

\footnotetext{
${ }^{16}$ janus sidabalok. Op cit. h.72

${ }^{17}$ Abdulkadir muhammad. Op.cit. h. 178
}

jasa serta untuk memperoleh keuntungan sesuai dengan isi pasal 12 Undang-Undang No. 19 Tahun 2003 tentang Badan Usaha Milik Negara menyatakan sebagai berikut:

"Maksud dan tujuan pendirian Persero adalah: a. menyediakan barang dan/atau jasa yang bermutu tinggi dan berdaya saing kuat; b. mengejar keuntungan guna meningkatkan nilai perusahaan".

\section{E. Sejarah PT Kereta Api Indonesia}

\section{(Persero)}

Sejarah kereta api di Indonesia dimulai ketika Indonesia dijajah oleh kolonial belanda. Sejarah itu dimulai jumat, 7 juni 1864, ketika gubenur jendral Hindia Belanda, Mr. L.A.J.W. baron Sloet Van De Beele menghunjamkan cangkul sebagai tanda dimulainya pembangunan jalan kereta api di Semarang. ${ }^{18}$

Perubahan bentuk perusahaan kereta api sendiri berubah beberapa kali, sejarah awal menjadi perseroan terbatas dimulai pada tahun 1998 berdasarkan PP No.19 tahun 1998 berubah menjadi PT Kereta Api (Persero). ${ }^{19}$

Bentuk perseroan terbatas dipertahankan hingga saat ini. Pada tahun 2010 direksi menganggap penting memasukan kata Indonesia pada nama perusahaan perseroan. Melalui Instruksi Direksi No. 16/OT.203/KA 2010, nama resmi perusahaan perseroan menjadi PT Kereta Api Indonesia (Persero). ${ }^{20}$

\section{F. Latar Belakang Pengalihan}

\section{Bentuk Perusahaan}

Faktor efisiensi pengelolaan BUMN menjadi persoalan yang sangat serius yang dihadapi perusahaan BUMN di Indonesia, dan merupakan salah satu faktor yang menyebabkan kerugian BUMN tersebut. Sebagian besar BUMN dikelola secara tidak efisien

\footnotetext{
${ }^{18}$ Hadi M Djuraid. jonan dan evolusi kereta api indonesia. Jakarta. 2013. h.21

${ }^{19}$ Yati nurhayati. Sejarah kereta api Indonesia. Bandung. 2014.h.61

${ }^{20}$ Hadi M Djuraid. Op.Cit. h.218
} 
karena faktor eksternal dan internal. Faktor eksternal yang mempengaruhi efisiensi efisiensi sehingga menjadi tidak efisien antara lain masih terlalu banyak regulasi dan birokrasi. Sistem pemerintahan di Indonesia tidak efisien disebabkan karena ekonomi biaya tinggi, monopoli terselubung, kurangnya visi dari pemerintah, kebocoran anggaran pemerintah dan kolusi antara oknum pejabat pemerintah dengan pengusaha. ${ }^{21}$

Karena adanya permasalahan BUMN tersebut pemerintah merespon dengan berbagai kebijakan. Sebagai respon tersebut pemerintah merespon Dengan dikeluarkannya salah satu Peraturan Pemerintah Tentang Perusahaan Persero yaitu PP No. 12 Tahun 1998 tentang Perusahaan Persero. Melalui PP ini dengan jelas adanya pembatasan intervensi pemerintah yang terlalu jauh dalam menejemen BUMN dengan memberikan kebebasan kepada BUMN Persero dengan sepenuhnya kewenangan diserahkan kepada direksi untuk mengurus perseroan dengan mengacu pada prinsip-prinsip korporasi yang sehat. Selanjutnya pada tahun 2003 diundangkan UU No. 19 Tahun 2003 tentang BUMN dan mewajibkan BUMN menerapkan tata kelola perusahaan yang baik. BUMN tidak lagi difokuskan menjalankan fungsi sebagai unsur penggerak pembangunan saja tetapi juga sebagai unsur penggerak bisnis yang berperan dalam menghasilkan laba setinggi-tingginya bagi negara sebagai pemegang saham.

Dengan adanya permasalahan yang tersebut diatas yang menjadi latar belakang pemerintah melakukan pengalihan bentuk Perusahaan Umum (PERUM) Kereta Api menjadi PT. Kereta Api Indonesia (Persero). Tujuan dari Pengalihan bentuk Perusahaan Umum (PERUM) Kereta Api menjadi PT. Kereta Api Indonesia (Persero) adalah agar perusahaan mampu meraih keuntungan atau laba sebanyak-banyaknya.

Dengan adanyapengalihan tersebut diharapkan perusahaan

${ }^{21}$ Marwah M. Diah, Restrukturisasi BUMN di Indonesia, Victory Jaya Abadi, Jakarta 2003. h.246

persero akan dikelola secara profesional dan mandiri dengan pengelolaan yang berbasis pada penerapan prinsip-prinsip tata kelola perusahaan yang baik(good corporate governance/GCG). Dengan konsep pengelolaan yang baik, PT. Kereta Api Indonesia diharapkan akan terlepas dari ketergantungannya terhadap Negara baik dari segi pembiayaan, kebijakan, maupun pembinaan.

- HAK-HAK

SETELAH

PENGALIHAN

PERUSAHAAN

MENJADI

TERBATAS
KARYAWAN

ADANYA

BENTUK

KERETA API PERSEROAN

\section{A. Hak-Hak Pegawai Perum Kereta} Api

$\begin{aligned} & \text { Dasar } \\ & \text { hukum } \\ & \text { Perumka didirikannya } \\ & \text { adalah }\end{aligned}$
Pemerintah Nomor 57 Tahun 1990
tentang Pengalihan
Perusahaan Jawatan (PERJAN)
Kereta Api menjadi Perusahaan
Umum (PERUM) Kereta Api.
Status kepegawaiannya adalah
Pegawai Perum sesuai Peraturan
Pemerintah No. 13 Tahun 1998
tentang Perusahaan Umum
(PERUM) yang berbunyi:

"Pegawai Perum merupakan pekerja Perum yang pengangkatan dan pemberhentian, kedudukan, hak serta kewajibannya ditetapkan berdasarkan perjanjian kerja sesuai dengan perundangundangan di bidang ketenagakerjaan".

Perlu adanya Surat Keputusan Bersama (SKB) tiga Menteri sebagai dasar penentuan status pegawai, sesuai Pasal 57 Peraturan Pemerintah No. 57 Tahun 1990 tentang pengalihan bentuk Perusahaan Jawatan (PERJAN) Kereta Api menjadi Perusahaan Umum (PERUM) Kereta Api sebagai berikut: "Penyelesaian pengalihan status
Pegawai Perusahaan Jawatan
(Perjan) Kereta Api menjadi
Pegawai Perusahaan 
(Perum) Kereta Api diatur lebih lanjut oleh Menteri perhubungan, Menteri Keuangan dan Menteri Pendayagunaan Aparatur Negara".

Namun Surat Keputusan Bersama (SKB) tiga menteri tersebut belum pernah dikeluarkan sampai saat ini dan sepanjang Surat Keputusan Bersama (SKB) tiga menteri tersebut belum dikeluarkan maka pembinaan pegawai dilaksanakan oleh Kepala Jawatan Kereta Api sebagaimana diatur dengan SK Menhub No. 5/KP.008/Phb-88 tertanggal 4 Agustus 1988 dan KP 16/KP.008/Phb-89 tertanggal 5 September $1989 .{ }^{22}$

Pengaturan pembinaan pegawai juga didasarkan pada surat Kepala Biro Kepegawaian Dephub No. SE.2/KP.001/PHB-91 tanggal 28 Februari 1991 tentang Mono status Pegawai Perum di lingkungan Dephub. Serta surat Sekjen Dephub Nomor: KP.304/2/2Phb-91 tanggal 8 Februari 1991 tentang Pembinaan Pegawai Perumka. Selanjutnya ada juga keputusan Menhub No. 7 Tahun 1992 tanggal 2 Maret 1992 tentang Petunjuk Pelaksanaan Pengalihan Status Kepegawaian dari PNS PJKA menjadi pegawai Perumka. Intinya menyebutkan pegawai yang terhitung mulai tanggal 1 april 1992 berumur 50 tahun status kepegawaiannya adalah PNS yang diperbantukan di perusahaan Perum kereta api. Sedangkan pegawai yang belum mencapai usia tersebut maka status kepegawaiannya dialihkan menjadi pegawai Perum kereta api. ${ }^{23}$

Yang menjadi dasar pembinaan PNS yang diperbantukan pada perusahaan Perumka adalah mengacu pada Undang-Undang No. 8 Tahun 1974 tentang PokokPokok Kepegawaian dan Pengelolaan Dana Pensiunnya oleh PT. Taspen (Persero). Sedangkan yang menjadi dasar pembinaan

\footnotetext{
${ }^{22}$ Supardi. Tesis. Implikasi Perubahan Bentuk Perumka Menjadi Persero Terhadap Hak-Hak Karyawan PT. Kereta Api Indonesia. Program Studi Ilmu Hukum, Sekolah Pascasarjana Universitas Sumatera Utara. Tahun 2009.h.78-79

${ }^{23} \mathrm{lbid}$. h.79
}

kepegawaian dengan status pegawai Perumka mengacu pada Pasal 15 Peraturan Pemerintah No. 57 tahun 1990. Selanjutnya isi pasal 53 Peraturan Pemerintah No. 13 Tahun 1998 tentang Perusahaan Umum (PERUM) tanggal 17 Januari 1998 menyatakan sebagai berikut:

$\begin{array}{lrr}\text { "Pegawai PERUM merupakan } \\ \text { pekerja PERUM yang } \\ \text { pengangkatan } & \text { dan } \\ \text { pemberhentian, kedudukan, hak } \\ \text { serta kewajibannya ditetapkan } \\ \text { berdasarkan perjanjian kerja } \\ \text { sesuai dengan perundang- } \\ \text { undangan di r bidang } \\ \text { ketenagakerjaan". }\end{array}$

\section{B. Hak-Hak karyawan PT Kereta Api Indonesia (Persero)}

Dasar yang digunakan dalam hal proses pengalihan status pegawai Perumka menjadi pegawai PT Kereta api adalah Peraturan Pemerintah Nomor 19 Tahun 1998 tentang tentang pengalihan bentuk perusahaan umum (PERUM) Kereta Api menjadi Perusahaan Perseroan (Persero). Akte Notaris pendirian oleh Imas Fatimah, SH. No. 2 Tahun 1999 tanggal 1 Juni tentang pendirian Perusahaan (Persero) PT. Kereta Api (Persero). Masa status persero tersebut adalah di mulai 1 Juni 1999 hingga saat ini. Status pegawainya adalah pegawai persero. Adapun mengenai pembinaan kepegawaiannya tunduk pada Undang-Undang Ketenagakerjaan.

Aturan mengenai kepegawaian Badan Usaha Milik Negara (BUMN) pada awalnya dipersamakan dengan Pegawai Negeri Sipil (PNS) karena belum ada aturan khusus yang mengatur tentang kepegawaian BUMN. Akan tetapi sejak diterbitkannya Peraturan Pemerintah No. 45 Tahun 2005 tentang Pendirian, Pengurusan, Pengawasan, dan Pembubaran Badan Usaha Milik Negara, segala ketentuan kepegawaian pada Pegawai Negeri Sipil tidak berlaku lagi terhadap Pegawai/Karyawan Badan Usaha Milik Negara sebagaimana dijelaskan dalam Pasal 95 
Peraturan Pemerintah No. 45 tahun 2005.

Belum ada Undang-Undang yang secara khusus mengatur tentang kepegawaian Karyawan BUMN. Yang menjadi dasar pengaturan kepegawaian karyawan BUMN adalah Undang-Undang Ketenagakerjaan, Peraturan Perusahaan dari Badan Usaha Milik Negara yang tidak bertentangan dengan aturan perundangundangan, dan Perjanjian Kerja Bersama (PKB) antara serikat pekerja dengan perusahaan yang sudah disepakati bersama.

\section{Hak-Hak Karyawan PT Kereta Api (Persero) Sesuai Perjanjian Kerja Bersama Periode 2017-2019}

Penjelasan Perjanjian Kerja Bersama (PKB) Sesuai dengan isi pasal 1 angka 21 Undang-Undang No. 13 Tahun 2003 tentang ketenagakerjaan sebagai berikut:

"Perjanjian kerja bersama
adalah perjanjian yang
merupakan hasil perundingan
antara serikat pekerja/serikat
buruh atau beberapa serikat
pekerja/serikat buruh yang
tercatat pada instansi yang
bertanggung jawab di bidang
ketenagakerjaan dengan
pengusaha, atau beberapa
pengusaha atau perkumpulan
pengusaha yang memuat syarat
syarat kerja, hak dan kewajiban
kedua belah pihak".

Sedangkan isi dari Perjanjian Kerja Bersama (PKB) dijelaskan Dalam Pasal 124 angka 1 UndangUndang No.13 Tahun 2003 sebagai berikut:

"Perjanjian kerja bersama paling sedikit memuat: hak dan kewajiban pengusaha, hak dan kewajiban serikat pekerja/serikat buruh serta pekerja/buruh, jangka waktu dan tanggal mulai berlakunya perjanjian kerja bersama, dan tanda tangan para pihak pembuat perjanjian kerja bersama".

Sesuai dengan isi pasal 2 ayat 1 dan 2 Perjanjian Kerja Bersama PT Kereta Api Indonesia (Persero) dengan Serikat Pekerja Kereta Api periode 2017-2019 maksud dan tujuan Perjanjian Kerja Bersama (PKB) sebagai berikut: ${ }^{24}$

a) Maksud dibuatnya PKB ini adalah sebagai pedoman bagi para Pihak untuk menciptakan keharmonisan, keseimbangan hubungan kerja dan bersinergi dalam meningkatkan produktivitas Pekerja, dan kesejahteraan Pekerja sesuai dengan ketentuan peraturan perundang-undangan

Ketenagakerjaan.

b) Tujuan dibuatnya PKB ini adalah untuk menjamin kepastian hukum bagi para Pihak dalam hubungan industrial secara proporsional serta menciptakan hubungan kerja yang dinamis dan bersinergi sesuaidengan ketentuan peraturan perundangundangan Ketenagakerjaan.

Ruang lingkup sesuai dengan pasal 3 Perjanjian Kerja Bersama PT Kereta Api Indonesia (Persero) dengan Serikat Pekerja Kereta Api periode 2017-2019 sebagai berikut: $^{25}$

a) PKB ini berlaku dan mengikat para pihak, termasuk seluruh Pekerja.

b) Pekerja Perusahaan sebagaimana dimaksud pada ayat (1) terdiri dari:

1) Pekerja eks PNS Dephub;

2) Pekerja eks Perumka, Pekerja PT. KAI (Persero) sampai Agustus 2009;

3) Pekerja PT. KAI (Persero) setelah Agustus 2009.

c) para Pihak sepakat bahwa PKB ini hanya mengatur kewajiban, hak, larangan serta syarat-syarat kerja Pekerja dan hubungan kemitraan antara para Pihak.

Hak-hak pekerja pekerja sesuai dengan Perjanjian Kerja Bersama PT Kereta Api Indonesia (Persero) dengan Serikat Pekerja Kereta Api periode 2017-2019 sebagai berikut: ${ }^{26}$

${ }^{24}$ Perjanjain kerja bersama antara PT Kereta Api Indonesia dengan Serikat Pekerja Kereta Api. h.11-12 ${ }^{25}$ ibid. h. 12

${ }^{26}$ Ibid. h. 32-40 
a) penghasilan

b) uang lembur

c) cuti

d) jaminan social tenaga kerja

e) tabungan hari tua

f) santunan uang duka wafat

g) tambahan jaminan kesehatan

h) restitusi kesehatan

i) program kesehatan pensiunan

j) perlindungan terhadap kesehatan dan keselamatan kerja

k) fasilitas mutase

1) badan pembinaan olahraga dan kesenian

m) pembinaan jasmani dan rohani

n) koperasi

o) rumah perusahaan

p) pemberian kesejahteraan lainnya

\section{PENUTUP}

\section{A. Kesimpulan}

1. Perseroan Terbatas (PT) diatur dalam Undang-Undang Nomor 40 tahun 2007 tentang Perseroan Terbatas sedangkan Badan Usaha Milik Negara (BUMN) diatur dalam Undang-Undang No. 19 Tahun 2003 Tentang Badan Usaha Milik Negara.Dalam Undang-Undang No. 19 Tahun 2003 Tentang Badan Usaha Milik Negara hanya mengatur dua jenis perusahaan yaitu Perusahaan Perseroan (PERSERO) dan Perusahaan Umum (PERUM).Peralihan Perumka Menjadi PT Kereta Api Indonesia (Persero) disebabkan karena pengelolaan perusahaan secara tidak efisien karena faktor internal dan eksternal sehingga perlu adanya peralihan perusahaan dari Perumka menjadi PT Kereta Api Indonesia (Persero) sehingga dapat menerapkan tata kelola perusahaan yang baik (good corporate governance).

2. Pada masa PERUM kereta api ketidakjelasan hak-hak pegawai PERUM dikarenakan belum dikeluarkannya surat keputusan bersama tiga menteri, serta pada pasa PERUM kereta api tidak ada pembuatan Perjanjian Kerja Bersama (PKB) antara Perusahaan dengan serikat pekerja sebagai dasar penentuan hak-hak pekerja, sehingga banyak hakhak pegawai perum yang terabaikan. Sedangkan pada masa PT Kereta Api Indonesia hak-hak pegawai sudah jelas dan meningkat di karena sudah adanya
Perjanjian Kerja Bersama (PKB) antara Perusahaan dengan serikat pekerja sebagai dasar-dasar pemenuhan hakhak pegawai meskipun ada pasal-pasal yang masih belum terpenuhi.

\section{B. Saran}

1. Agar pemerintah melakukan pengawasan terhadap kinerja PT Kereta Api Indonesia agar dapat menerapkan tata kelola perusahaan yang baik (good corporate governance).

2. Diharapkan PT Kereta Api Indonesia (Persero) menjalankan Perjanjian Kerja Bersama (PKB) antara Perusahaan dengan serikat pekerja sesuai dengan isi pasal-pasal dalam perjanjian sebagai dasar-dasar pemenuhan hak-hak pegawai. Dan Dalam membuat dan menetapkan Perjanjian Kerja Bersama (PKB) antara Perusahaan dengan serikat pekerja harus disesuaikan dengan perundang-undangan yang ada, serta perlu adanya pengawasan dari pemerintah terhadap pelaksanaan PKB yang telah ditetapkan.

\section{E. DAFTAR PUSTAKA}

\section{A. LITERATUR}

Abdul kadir Muhammad, Hukum Perusahaan Indonesia, Penerbit Citra Aditya Bakti, Cetakan Keempat revisi, Bandung, Tahun 2010.

Abdul R. Saliman, Hukum Bisnis Untuk Perusahaan, Penerbit Kencana, Cetakan Keenam, Jakarta, Tahun 2005.

Danang sunyoto, Hak dan kewajiban bagi pekerja dan ppengusaha, Penerbit Pustaka yustisia, Yogyakarta, Tahun 2013

Hadi M Djuraid, Jonan \& Evolusi Kereta Api Indonesia, Penerbit Mediasuara Shakti, Jakarta, Tahun 2013.

Janus Sidabalok, Hukum Perusahaan, Penerbit Nuansa Aulia, Bandung, tahun 2012.

Johnny Ibrahim, Teori \& Metode Penelitian Hukum Normatif, PenerbitBanyumedia Publishing, Malang, Tahun 2006.

Marwah M. Diah, Restrukturisasi BUMN di Indonesia, Penerbit Victory Jaya Abadi, Jakarta, Tahun 2003.

Peter Mahmud Marzuki. Penelitian Hukum. Universitas Air Langga. Surabaya 2005. 
Jurnal Independen Fakultas Hukum

Yati Nurhayati, Sejarah Kereta Api Indonesia, Penerbit Sahabat, Bandung 2014.

Zainudin Ali, Metode Penelitian Hukum, Penerbit Sinar Grafika, Jakarta 2009. 